\title{
EFFECT OF ALPHA-AMYLASE AND XYLANASE ACTIVITIES ON PROPERTIES OF FROZEN DOUGH PREPARED FROM FLOURS OF DIFFERENT WHEAT VARIETIES
}

\author{
Eman* K.N. Hanafi, El-Shemy M.G.Y., Yousif E.I. and Nessrien M.N. Yasin
}

$[170]$

Food Sci. Dept., Fac. of Agric., Ain Shams Univ., P.O Box 68, Hadayek Shubra 11241, Cairo, Egypt

*Corresponding author:dr_eman_kamal@agr.asu.edu.eg

\section{ABSTRACT}

This study was to evaluate alpha-amylase and xylanase activities in flours of different wheat varieties. Various physicochemical characteristics of flours were studied. Thermal properties of prepared doughs were measured from its freezing curves. Alpha amylase and xylanase activities were assessed for doughs during 70 days of frozen storage at $-18 \pm 2^{\circ} \mathrm{C}$. Residual enzyme activities of pan breads made from frozen doughs were determined after $72 \mathrm{~h}$ of baking. Data revealed that, the variations in the proximate chemical composition among tested wheat flours could be attributed to the difference of wheat varieties and efficiency of milling process. Damaged starch (DS, \%) was significantly $(p \leq 0.05)$ higher in Shandaweel 1 flour (F1) and the mixture of $F 1$ and $F 2$ with $1: 1$ ratio (w/w) (F4) than in Sakha 94 flour (F2) and the local wheat flour (F3). Using of compressed yeast in dough preparation results in a considerable decline of freezing point which may be attributed to the difference in the amount of free water. The end freezing point ranged from $-16^{\circ} \mathrm{C}$ to $-9^{\circ} \mathrm{C}$. Flours were significantly $(p \leq 0.05)$ differed in their enzyme activities where, F4 had the highest $\alpha$-amylase activity followed by F2, F3 and F1, respectively. Whereas, xylanase activity was higher in F1 than in other tested flours. Dough samples had higher enzyme activity comparing to flour samples that were made from. A significant $(p \leq 0.05)$ increase in $\alpha$-amylase activity was recorded by extending the frozen storage period of dough up to 70 days at $18 \pm 2^{\circ} \mathrm{C}$; while it declined significantly $(P \leq 0.05)$ after bread baking as a result of the inactivation effect of baking temperature. Xylanase activity significantly $(p \leq 0.05)$ increased during the first 14 days of dough frozen storage then decreased gradually till the end of frozen storage period owing to the increase of $\mathrm{pH}$ values. Also, xylanase activity has the same behavior as $\alpha$-amylase for pan bread. There was a strong relationship between the storage time of dough and enzyme activities. The longer the frozen storage time of dough at $18^{\circ} \mathrm{C}$, the higher the decrease of bread residual enzyme activities. However, enzyme activities in the doughs and pan breads strongly depended on the flour and yeast types. Pan breads prepared from doughs with a high alpha-amylase activity had better specific volumes.

Key words: Wheat flour quality, Freezing curves, Frozen dough, Amylase activity, Xylanase activity, Specific volume.

\section{INTRODUCTION}

There are many varieties of wheat all over the world which are used for bread making (Baratto et al 2015). The quality of baked products is affected by the phenotypes and genotypes of wheat (Gholamin and Khayatnezhad, 2011).

Mature wheat grains contain several enzymes such as amylases, proteases, lipases and oxidases which vary in their activities due to the changes in the environmental conditions during growing and harvesting, and the genetic differences among wheat varieties. Some of these enzymes are active in different phases of wheat utilization in food manufacturing (storage, milling, mixing, leavening, kneading, shaping and baking). It is worth mentioning that the activity of endogenous enzymes in flour strongly affects the quality and nutritional properties of the end products and influences the 
behavior of raw materials during processing (Hidalgo et al 2013). Also, these enzymes play critical roles in cereal processability (Basinskiene et al 2011). Rani et al (2001) reported that, xylanase and amylase activities have a great impact on the functional properties of the flour.

Alpha-amylase (EC 3.2.1.1) is one of the most important endoenzymes that catalyzes the starch degradation by randomly hydrolyzing the $\alpha, 1-4$ bonds, resulting in the formation of linear and branched oligosaccharides, maltotriose, maltose and glucose but unable to cleave $\alpha, 1-6$ bonds. The $a$-amylase directly influences the water absorbance of flours, the viscosity of mixes, the fermentation activity of dough and the quality of end products. In fact, the higher the activity of $\alpha$ amylase, the lower the value of falling number and the more the reduction in viscosity. Moreover, $\alpha$ amylase activity is often assessed to deduce the manufacturing quality of flours (Hidalgo et al 2013). In addition, amylases can reduce the firming rate of bread crumb, have an anti-staling action which has been ascribed to the modification of retrogradation behavior for the hydrolyzed starch (Miguel et al 2013).

Xylanase (endo-1,4- $\beta$-xylanase, EC 3.2.1.8) catalyzes the endohydrolysis of $1,4-\beta$-D-xylosidic bonds in xylan and arabinoxylan (Courtin and Delcour, 2002), consequently promoting the redistribution of water in dough, thus modifying the functionality of arabinoxylans (AXs) during baking (Lebesi and Tzia, 2012). Moreover, Steffolani et al (2010) reported that xylanase plays a significant role in increasing the shelf-life of bread and have an anti-staling action during the bread storage. The effects of xylanase on dough properties and bread quality depend on flour quality, recipe and procedure of dough preparation as well as the bread type (Kornbrust et al 2012).

The breadmaking process starts with the dough formation throughout mixing of flour, water, yeast, salt, sugar and oil. Flour particles are hydrated during mixing, and dough develops once gluten proteins form a continuous cohesive network in which the starch granules are distributed. An optimal gluten network gives dough machinability, good gas retention, high volume of the bread and fine structure of the crumb. The characteristics of the final product are affected by physical and mechanical mixing, catalytic reactions of enzymes and the thermal effects (baking time and temperature) (Miguel et al 2013).

Freezing is one of the acceptable methods used for the preservation of dough. However, freezing conditions affects the properties of the dough and the baking quality of final bread. Recently, the production of frozen dough has considerably increased as a result of direct sales to customers and the increasing of the number of instore bakeries (Salas-Mellado and Chang, 2003). On the other hand, Selomulyo and Zhou, (2007) mentioned that, the storage of frozen dough for a long time cause a gradual loss of gluten matrix strength, a reduction of gas retention, a loss in yeast viability and a long time of proofing owing to the ice recrystallization. Such effects negatively influence the volume of loaf, the texture of crumb and the sensory attributes of the bread. These undesirable effects can be reduced by controlling the formulation of the dough. The deterioration of the quality of frozen dough could be ascribed to the redistribution of water (Hamed et al 2015) and the formation of ice crystals (Kim and Koh, 2002). The present study aimed to study the physicochemical properties of flour from two Egyptian wheat varieties and compare them with those of local wheat flour sample which were used in pan bread making. The activities of $\alpha$-amylase and xylanase of different prepared doughs and pan breads during their storage were determined. $\alpha$ amylase activity was also used to predict the shelflife of frozen doughs.

\section{MATERIALS AND METHODS}

\section{Materials}

Two Egyptian wheat varieties (Triticum aestivum L.), including Sakha 94 and Shandaweel 1, were purchased from Field Crops Research Institute, Agricultural Research Center, Giza, Egypt during season of 2016/2017 and 20 Kg's of wheat flour (72\% extraction) were obtained from Amoun for Milling Company, Giza, Egypt. Instant active dry yeast (Saccharomyces cerevisiae), crystal white sugar, salt and sunflower oil were purchased from the local market, Cairo, Egypt. Fresh compressed baker's yeast was obtained from Al- Hawamdia Co., Giza, Egypt. All chemicals used were of analytical grade. 


\section{Methods}

\section{Technological Methods}

\section{Preparation of wheat samples for milling}

Milling of wheat samples was carried out in the Egyptian Center for Milling Technology, Cairo, Egypt. Initially, twenty Kg's of each wheat were cleaned by Carter device (Carter-Day Company) to remove dirt, impurities and other foreign grains. After conditioning to $14 \%$ moisture and tempering for $24 \mathrm{~h}$, the wheat grains were milling in a Quadrumat Junior Mill (Wichita, Kansas, USA). Then, the whole meal was sieved through a 60-mesh sifter (Leavenworth, Kansas, USA) to obtain flour with $72 \%$ extraction.

\section{Pan bread making}

Bread samples were prepared with the flour of Egyptian wheat varieties Shandaweel 1 (F1) and Sakha 94 (F2), flour of Amoun Co. (F3) and a mixture of $F 1$ and $F 2$ with $1: 1$ ratio $(\mathrm{w} / \mathrm{w})(\mathrm{F} 4)$. The method of Bae et al (2014) was applied as follows: the dough recipe consisted of $100 \%$ wheat flour (14\% moisture basis), $2 \%$ instant dry and/ or compressed yeast, $6 \%$ sugar, $1.5 \%$ salt and $3 \%$ oil. The optimum water absorption and dough development time were determined from the Farinograph results. Eight bread formulas were prepared using the same quantity of all ingredients, four of them were prepared from $F 1, F 2, F 3$ and $F 4$ with the instant active dry yeast $(A, B, D$ and $A B$, respectively) whereas, the other four were prepared with the compressed yeast $(A C, B C, D C$ and $A B C$, respectively). For each formula, ingredients were mixed in a spiral mixer (KRUS model KMB400S, China) till the optimum dough consistency was obtained. After resting for $15 \mathrm{~min}$ at room temperature $\left(25 \pm 2^{\circ} \mathrm{C}\right)$, dough was divided into $150 \mathrm{~g}$ pieces, rounded, shaped by hand into $10 \mathrm{~cm}$ diameter and $1 \mathrm{~cm}$ thickness then packaged in polyethylene bags. Thereafter, dough pieces were frozen in a no-frost freezer (Kiriazi, Cairo, Egypt) at $-18 \pm 2^{\circ} \mathrm{C}$ (to, slow freezing). After completely freezing, the doughs were stored at $-18 \pm 2^{\circ} \mathrm{C}$ for 70 days.

At regular intervals during frozen storage (every 14 days), the frozen doughs were placed in an incubator at $30^{\circ} \mathrm{C}$ and $70 \%$ relative humidity $(\mathrm{RH})$ till the temperature at the center of the dough pieces, measured by thermocouples, reached $2^{\circ} \mathrm{C}$. After thawing, a sample of each dough was taken for measuring the $\mathrm{pH}$ and both of $\alpha$-amylase and xylanase activities. Other samples were punched with a dough sheeter, hand-molded, panned in metal bans and proofed in a fermentation incubator at $30^{\circ} \mathrm{C}$ and $85 \% \mathrm{RH}$ for $1 \mathrm{~h}$. Then, doughs were baked in an electric oven at $230^{\circ} \mathrm{C}$ for $20 \mathrm{~min}$. After $1 \mathrm{~h}$ of baking, specific volumes of pan breads and activities of $\alpha$-amylase and xylanase were determined.

\section{Analytical Methods}

\section{Physicochemical characteristics}

Moisture, ash, protein $(\mathrm{N} \times 5.7)$, total lipids, gluten content (wet, dry gluten and gluten index), damage starch level, falling number, liquefaction number (LN) of the wheat flour samples and $\mathrm{pH}$ values of the doughs were determined according to the methods of AACC, (2012).

\section{Freezing curves and thermal properties}

Time-temperature profiles (freezing curves) were recorded in the core of the dough using $\mathrm{K}$ type thermocouples. Thermal properties for different dough samples (freezing point, time of precooling, super cooling temperature and end freezing point) were obtained from the freezing curves. Enthalpy and \% freezable water were calculated from Enthalpy - composition chart for dough.

\section{Determination of the enzyme activity}

\section{Alpha-amylase activity}

The method of Rosell et al (2002) was applied to prepare the enzyme extract of $\alpha$-amylase which used for enzyme assay. The a-amylase activity was determined according to the method of Bernfeld, (1955) by monitoring the absorbance at $540 \mathrm{~nm}$. Maltose was used as a standard and the results were expressed as $\mu$ mole of maltose liberated / $\min$ at $\mathrm{pH} 5$ and $37^{\circ} \mathrm{C}$ (Rani et al 2001).

\section{Xylanase activity}

Xylanase was extracted as described in the method of Simsek et al (2010) and its activity was determined according to the method described by Miller, (1959) using beechwood xylan as a substrate and 3,5-dinitrosalicylic acid (DNS) to measure the amount of the xylose produced by the $x y$ lanase at $540 \mathrm{~nm}$. One unit of xylanase activity was defined as $\mu$ mole of xylose liberated / $\mathrm{min}$ at $\mathrm{pH} 4.5$ and $40^{\circ} \mathrm{C}$. 


\section{Specific volume of pan bread}

After $1 \mathrm{~h}$ of cooling at $25 \pm 2^{\circ} \mathrm{C}$, each loaf was weighted in grams and loaf volume $\left(\mathrm{cm}^{3}\right)$ was measured using rapeseed displacement method according to the method of AACC, (2012). Specific loaf volume was calculated as $\mathrm{cm}^{3} / \mathrm{g}$ by dividing the volume of the bread loaf by its weight.

\section{Statistical analysis}

The data were statistically analyzed using the Statistical Analysis System software (SAS, 2004) by one-way analysis of variance (ANOVA). Difference among mean values were compared using Duncan's Multiple range test at a significant level of $95 \%$ ( $p \leq 0.05)$. Linear regression analysis was carried out using Microsoft Excel as follows:

$$
y=a+b(x)
$$

Where, (y), ( $\alpha$ ) and (b) are $\alpha$-amylase ( $\mu \mathrm{g}$ maltose $/ \mathrm{ml} / \mathrm{min}$ ) or xylanase ( $\mu \mathrm{g}$ xylose $/ \mathrm{ml} / \mathrm{min}$ ) activities, intercept and slope, respectively and $x$ is the frozen storage period of dough at $-18^{\circ} \mathrm{C}$ (in days).

\section{RESULTS AND DISCUSSION}

\section{Physicochemical characteristics of wheat flours}

The physicochemical parameters of different wheat flours are presented in Table 1. Results revealed that, the percentages of moisture, protein, ash, lipids and total carbohydrates (calculated by difference) for F1, F2, F3 and F4 ranged between $10.71-11.71 \%, 11.48-11.71 \%, 0.43-0.50 \%, 0.61-$ $1.10 \%$ and $75.27-76.59 \%$, respectively. The moisture content was significantly $(p \leq 0.05)$ lower in F3 than in other tested flours. The mixing of F1 and F2 didn't affect significantly the moisture content. Where, there was a non-significant difference $(p \geq 0.05)$ among $F 1, F 2$ and F4 flour samples. Moisture content is an essential estimation for evaluating the flour quality because it affects the enzyme activity and the mixing properties of dough. On the other hand, the protein content was significantly $(p \leq 0.05)$ higher in F1 and F4 than in F3 and F2 samples. Non-significant difference $(p \geq 0.05)$ was observed in ash content for all tested flour samples. Also, F3 showed the lowest lipids content and the highest level of total carbohydrates compared with other tested samples. The variations in the proximate chemical composition of tested wheat flours could be attributed to the differences of wheat varieties and the efficiency of milling process (Stathopoulos et al 2008).

The wet gluten content for all tested flours was more than $22 \%$. These results are similar with those of Paucean et al (2016) who mentioned that the minimum value of wet gluten for the wheat flour used in bread making shouldn't be less than $22 \%$. Moreover, the dry gluten contents were $8.97 \%$, $10.17,8.67$ and $9.80 \%$ for F1, F2, F3 and F4, respectively. Amjid et al (2013) and Ferrari et al (2014) reported that, gluten quality and quantity affects the functional properties of flour and the quality of bakery products. Data also showed that, F3 recorded the highest value of gluten index (96.21\%) followed by F4 (91.53\%), F2 (88.79\%) and $F 1(86.48 \%)$. The wheat flours with gluten index in the range of $75-95 \%$ provides the optimal bread making quality (Curic et al 2001). The obtained results also indicated that, F2 had the highest specific sedimentation value (2.67) followed by F4 (2.31), F3 (2.20) and F1 (2.05). The specific sedimentation value gives an idea about the quality of the gluten and the bread loaf volume (Gomez et al 2011).

The falling number (FN) is an important quality characteristic of cereal products (Struyf et al 2016). Flours with a high FN (>350 s) have a reduced capability to form fermentable sugars (Codina and Leahu, 2009), while flours with a low FN (<250 s) yielded dough that is difficult to handle and bread with a sticky crumb (Every and Ross, 1996). To avoid this quality loss Goesaert et al (2009) reported that the FN of flour should be adjusted to 250-300 s. The FN of the tested flour samples ranged between $365 \mathrm{sec}$ for $\mathrm{F} 3$ and 451 sec for F1. These results were in the range measured by Rakita et al (2015). Damaged starch (DS, $\%)$ was significantly $(p \leq 0.05)$ higher in $F 1$ and $F 4$ than in F2 and F3 samples. Mixing of F1 and F2 significantly $(p \leq 0.05)$ reduced the $F N$ value as well as increased the liquefaction number (LN) and DS level. According to Kornbrust et al (2012), the amount of DS is dependent on wheat hardness and milling conditions.

\section{Thermal parameters of different prepared doughs during freezing}

Data in Table 2 shows thermal properties for various prepared doughs. Regarding freezing point $\left(\mathrm{t}_{\mathrm{f}}\right)$, data revealed that, the $\mathrm{t}_{\mathrm{f}}$ values of the doughs contained instant dry yeast was in the range of -3 (A) and $-5^{\circ} \mathrm{C}(\mathrm{AB})$. While it was in the range of -1 
Table 1. Physicochemical properties of different wheat flours

\begin{tabular}{|c|c|c|c|c|}
\hline \multirow[b]{2}{*}{ Parameters } & \multicolumn{4}{|c|}{ Flour samples } \\
\hline & F1 & F2 & F3 & F4 \\
\hline Moisture (\%) & $11.71^{\mathrm{A}}$ & $11.53^{\mathrm{A}}$ & $10.71^{\mathrm{B}}$ & $11.33^{\mathrm{A}}$ \\
\hline Crude protein $(\%)^{*}(\mathrm{~N} \times 5.7)$ & $11.71^{\mathrm{A}}$ & $11.48^{\mathrm{C}}$ & $11.58^{\mathrm{B}}$ & $11.68^{\mathrm{A}}$ \\
\hline Ash $(\%)^{*}$ & $0.46^{\mathrm{A}}$ & $0.43^{\mathrm{A}}$ & $0.50^{\mathrm{A}}$ & $0.44^{\mathrm{A}}$ \\
\hline Lipids (\%)* & $0.86^{\mathrm{B}}$ & $0.73^{\mathrm{BC}}$ & $0.61^{\mathrm{C}}$ & $1.10^{\mathrm{A}}$ \\
\hline Total carbohydrates (\%)* & $75.27^{C}$ & $75.84^{\mathrm{B}}$ & $76.59^{A}$ & $75.44^{\mathrm{C}}$ \\
\hline Wet gluten content $(\%)^{* *}$ & $26.70^{\mathrm{B}}$ & $29.47^{\mathrm{A}}$ & $23.03^{C}$ & $26.83^{\mathrm{B}}$ \\
\hline Dry gluten content $(\%)^{\star \star}$ & $8.97^{\mathrm{BC}}$ & $10.17^{\mathrm{A}}$ & $8.67^{C}$ & $9.80^{\mathrm{AB}}$ \\
\hline Gluten index (\%) & $86.48^{\mathrm{D}}$ & $88.79^{C}$ & $96.21^{\mathrm{A}}$ & $91.53^{\mathrm{B}}$ \\
\hline Specific Sedimentation value ${ }^{* *}$ & $2.05^{\mathrm{D}}$ & $2.67^{\mathrm{A}}$ & $2.20^{C}$ & $2.31^{\mathrm{B}}$ \\
\hline Falling Number $(\mathrm{FN}, \mathrm{sec} .)^{\star *}$ & $451^{A}$ & $448^{\mathrm{B}}$ & $365^{\mathrm{D}}$ & $428^{C}$ \\
\hline Liquefaction Number $(\mathrm{LN})^{\star *}$ & $14.95^{\mathrm{D}}$ & $15.09^{C}$ & $19.05^{\mathrm{A}}$ & $15.89^{\mathrm{B}}$ \\
\hline Damaged starch (DS, \%) & $6.40^{\mathrm{A}}$ & $5.10^{\mathrm{B}}$ & $4.73^{\mathrm{B}}$ & $6.67^{A}$ \\
\hline
\end{tabular}

* On dry basis $\quad$ ** On 14\% moisture basis. $\quad$ LN $=6000 /$ (Falling Number-50).

-Means followed by different capital letters in the same row are significantly different $(p \leq 0.05)$.

Table 2. Thermal properties of different prepared doughs during freezing at $-18 \pm 2{ }^{\circ} \mathrm{C}$

\begin{tabular}{|c|c|c|c|c|c|c|c|c|}
\hline \multirow{3}{*}{$\begin{array}{l}\text { Dough } \\
\text { Samples }\end{array}$} & \multicolumn{8}{|c|}{ Freezing parameters of dough } \\
\hline & \multirow[b]{2}{*}{$t_{f}\left({ }^{\circ} \mathrm{C}\right)$} & \multirow{2}{*}{$\begin{array}{l}\text { Time of precooling } \\
\text { (min) }\end{array}$} & \multicolumn{3}{|c|}{$t_{s}\left({ }^{\circ} \mathrm{C}\right)$} & \multirow{2}{*}{$\begin{array}{c}t_{e} \\
\left({ }^{\circ} \mathrm{C}\right)\end{array}$} & \multirow{2}{*}{$\begin{array}{c}\Delta \mathrm{H} \\
(\mathrm{Kcal} / \mathrm{Kg})\end{array}$} & \multirow{2}{*}{$\begin{array}{c}\alpha \\
(\%)\end{array}$} \\
\hline & & & ts 1 & $\mathbf{t s}_{2}$ & ts $_{3}$ & & & \\
\hline A & -3 & 100 & -8 & -5 & -6 & -14 & 39 & 60 \\
\hline B & -4 & 115 & -6 & & & -16 & 39 & 58 \\
\hline $\mathrm{D}$ & -4 & 75 & -5 & -5 & & -14 & 36 & 50 \\
\hline$A B$ & -5 & 120 & -6 & & & -12 & 39 & 55 \\
\hline$A C$ & -1 & 140 & -2 & & & -9 & 34 & 50 \\
\hline $\mathrm{BC}$ & -1 & 115 & -3 & & & -12 & 38 & 53 \\
\hline DC & -1 & 90 & -3 & -4 & & -14 & 37.5 & 53 \\
\hline$A B C$ & -2 & 90 & -5 & & & -14 & 37 & 55 \\
\hline
\end{tabular}

$\mathbf{t}_{\mathbf{f}}$ : freezing point, $\mathbf{t s}_{\mathbf{s}}$ : super cooling temperature, $\mathbf{t}_{\mathbf{e}}$ : end freezing point, $\Delta \mathbf{H}$ : enthalpy and $\alpha$ : \% freezable water.

for $\mathrm{AC}, \mathrm{BC}$ and $\mathrm{DC}$, and $-2^{\circ} \mathrm{C}$ for $\mathrm{ABC}$. Therefore, the difference of yeast type affects the $t_{f}$ values which can be explained by the difference of tissue structure, cell juice concentration and heat exchange conditions (Kozlowicz and Kluza, 2001). On the other hand, it could be noticed that, the time of precooling was lower in $D(75 \mathrm{~min})$ followed by $D C$ and $A B C$ (90 min), A (100 min), B and BC (115 min), $A B(120 \mathrm{~min})$ and $A C$ (140 min). Such differences may be due to the variation in wheat variety and the type of yeast. Also, some of the dough samples clearly had more than one point of super cooling ( $t_{\mathrm{s}}$ ) i.e. A, D and DC.

For the end freezing point $\left(t_{e}\right)$ that correlated well with $t_{0}$, results showed that, it ranged from $16^{\circ} \mathrm{C}$ for $\mathrm{B}$ to $-9^{\circ} \mathrm{C}$ for $\mathrm{AC}$. Using of $\mathrm{F} 4$ with active dry yeast in dough preparation cause an increase in $t_{e}$ value compared with the value of $t_{e}$ for doughs made from F1 or F2. While, a decrease in te value was recorded when F4 and compressed yeast were used for dough preparation in comparison with that prepared from F1 and F2. Such findings probably attributed to the decrease in free water amount in the first case (lower a value), and vice versa in the second case (higher a value).

Concerning the proportion of freezable water $(\boldsymbol{\alpha}, \%)$ and enthalpy $(\Delta \mathbf{H})$, results indicated that, the fraction of un-freezable water almost varied from $0.4 \mathrm{~g} / \mathrm{g}$ of dough $(A)$ to $0.5 \mathrm{~g} / \mathrm{g}$ of dough (D and $A C)$. These values are higher than those reported by Matuda et al (2011). Such variations in unfreezable water content are probably due to the 
differences in dough formula, cooling rate and freezing procedure. Laaksonen and Roos, (2000) noted a low value of the un-freezable water $(0.35 \mathrm{~g}$ water/g solute) when the dough formulation contained a large amount of maltose.

\section{Alpha-amylase activity in tested wheat flours}

a-amylase activity in different wheat flours is given in Table 3. Results showed that, there were significant $(p \leq 0.05)$ differences in $\alpha$-amylase activity among flour samples. Where, F4 had the highest $\alpha$-amylase activity followed by F2, F3 and F1, respectively. $\alpha$-amylase activity in $\mathrm{F} 2$ was approximately more than two times comparing with the $\alpha$ amylase activity in F1. The mixing of $F 1$ and $F 2$ significantly $(p \leq 0.05)$ increased the activity of $\alpha$ amylase compared with F1 which had the lowest value of $\alpha$-amylase activity. The $\alpha$-amylase activity in $\mathrm{F} 1$ was less than the range estimated by Rani et al (2001), but F2, F3 and F4 were in the range. The variations in $\alpha$-amylase activity which have a strong influence on the quality of flour and end products may be due to the impact of cropping environment, the genetic differences among wheat varieties (Mares and Marva, 2008) and the effect of milling process on DS level (Struyf et al 2016). These observations coincide with those of Hidalgo et al (2013).

Table 3. Alpha-amylase activity in different wheat flours

\begin{tabular}{|c|c|}
\hline $\begin{array}{c}\text { Flour } \\
\text { samples }\end{array}$ & $\begin{array}{c}\text { a-amylase activity }(\boldsymbol{\mu m o l e} \\
\text { maltose/ml/min) }\end{array}$ \\
\hline F1 & $0.144^{\mathrm{D}}$ \\
F2 & $0.370^{\mathrm{B}}$ \\
F3 & $0.276^{\mathrm{C}}$ \\
F4 & $0.450^{\mathrm{A}}$ \\
\hline
\end{tabular}

- Means followed by different capital letters in the column are significantly different $(p \leq 0.05)$.

\section{Alpha-amylase activity in different prepared doughs}

The effect of frozen storage at $-18 \pm 2^{\circ} \mathrm{C}$ on $\alpha$ amylase activity in different prepared doughs contained instant dry or compressed yeast are shown in Table 4. It could be noticed that, the dough samples had higher enzyme activity comparing to flour samples which were made from. Such findings are coincide with Rani et al (2001) who mentioned that, amylases become active and affect the functional properties of the dough as a result of adding water to flour. The initial activity of $\alpha$ amylase in the fresh doughs was significantly $(p \leq 0.05)$ differed where, $A B C$ recorded the highest activity of $\alpha$-amylase followed by $B C, A B, B$, both of $A C$ and $D C, D$ and $A$, respectively.

On the other hand, results showed a significant $(p \leq 0.05)$ increase in $\alpha$-amylase activity by extending the frozen storage period of dough up to 70 days at $-18 \pm 2^{\circ} \mathrm{C}$. These results suggest that the changes in $\mathrm{pH}$ values (Fig. 1) correlated well with the enzyme activity. After 70 days of storage at $18^{\circ} \mathrm{C}$, the $A$ sample had the lowest $\alpha$-amylase activity followed by $D, A C, D C$, both of $B$ and $A B$, and both of $A B C$ and $B C$, respectively. In this context, Struyf et al (2016) reported that $\alpha$-amylase activity is a limiting factor for the release of reduced sugars in dough during mixing and fermentation.

Additionally, Table 5 illustrates the equations that expect $\alpha$-amylase activity in different prepared doughs within any period of frozen storage at $18 \pm 2^{\circ} \mathrm{C}$. The regression analysis indicated that there was a strong correlation between storage time and $\alpha$-amylase activity $\left(R^{2}\right.$ were in the range of $0.870-0.995)$. These equations could be valuable in the identification of the optimal time of dough frozen storage through associating the enzyme activity with the quality characteristics of dough (e.g. rheological parameters and fermentation activity) and bread made from them (e.g. specific volume, crumb texture, crust color, staling rate and sensory properties). They also may be used as a guide for determining the most suitable treatments for bread making.

\section{Alpha-amylase activity in different pan breads made by frozen doughs}

Data in Table 6 shows the a-amylase activity in different pan breads made by frozen doughs after $1 \mathrm{~h}$ of baking and storage at $25 \pm 2^{\circ} \mathrm{C}$. Generally, data concluded that, the $\alpha$-amylase activity of breads was affected by the flour and yeast types, as well as the storage time of frozen dough at $18 \pm 2^{\circ} \mathrm{C}$. Where, the pan breads made from $\mathrm{F} 2$ significantly $(p \leq 0.05)$ recorded higher $\alpha$-amylase activity than those prepared by F1 or F3 whether yeast was used in fresh or instant dry form. Whenever using the same type of flour, $\alpha$-amylase activity was significantly $(p \leq 0.05)$ higher in pan breads prepared using compressed yeast than those prepared using active dry yeast. These values of bread $\alpha$-amylase activity were lower than those reported by Hemalatha et al (2010). Such variations may be due to the differences of tested wheat 

Dough Prepared From Flours of Different Wheat Varieties

Table 4. Alpha-amylase activity in different prepared doughs during 70 days of storage at $-18 \pm 2^{\circ} \mathrm{C}$

\begin{tabular}{|c|c|c|c|c|c|c|}
\hline \multirow{2}{*}{ Dough samples } & \multicolumn{6}{|c|}{$\boldsymbol{\alpha}$-amylase activity ( $\mu$ mole maltose/ml/min) during frozen storage period (days) } \\
\cline { 2 - 6 } & $\mathbf{0}$ & $\mathbf{1 4}$ & $\mathbf{2 8}$ & $\mathbf{4 2}$ & $\mathbf{5 6}$ & $\mathbf{7 0}$ \\
\hline A & $0.218^{\mathrm{Ff}}$ & $0.373^{\mathrm{Fe}}$ & $0.428^{\mathrm{Hd}}$ & $0.677^{\mathrm{Gc}}$ & $0.802^{\mathrm{Hb}}$ & $0.927^{\mathrm{Fa}}$ \\
$\mathbf{B}$ & $0.501^{\mathrm{Cf}}$ & $0.541^{\mathrm{Ce}}$ & $0.629^{\mathrm{Dd}}$ & $0.920^{\mathrm{Dc}}$ & $1.065^{\mathrm{Db}}$ & $1.210^{\mathrm{Ba}}$ \\
D & $0.301^{\mathrm{Ef}}$ & $0.412^{\mathrm{Ee}}$ & $0.470^{\mathrm{Gd}}$ & $0.729^{\mathrm{Fc}}$ & $0.859^{\mathrm{Gb}}$ & $0.988^{\mathrm{Ea}}$ \\
AB & $0.540^{\mathrm{Bf}}$ & $0.631^{\mathrm{Be}}$ & $0.718^{\mathrm{Cd}}$ & $0.966^{\mathrm{Cc}}$ & $1.091^{\mathrm{Cb}}$ & $1.215^{\mathrm{Ba}}$ \\
AC & $0.434^{\mathrm{Df}}$ & $0.484^{\mathrm{De}}$ & $0.524^{\mathrm{Fd}}$ & $0.828^{\mathrm{Ec}}$ & $0.955^{\mathrm{Fb}}$ & $1.081^{\mathrm{Da}}$ \\
BC & $0.555^{\mathrm{Bc}}$ & $0.699^{\mathrm{Ab}}$ & $1.253^{\mathrm{Aa}}$ & $1.251^{\mathrm{Aa}}$ & $1.250^{\mathrm{Aa}}$ & $1.250^{\mathrm{Aa}}$ \\
DC & $0.434^{\mathrm{Df}}$ & $0.478^{\mathrm{De}}$ & $0.576^{\mathrm{Ed}}$ & $0.825^{\mathrm{Ec}}$ & $0.976^{\mathrm{Eb}}$ & $1.127^{\mathrm{Ca}}$ \\
ABC & $0.660^{\mathrm{Af}}$ & $0.693^{\mathrm{Ae}}$ & $0.835^{\mathrm{Bd}}$ & $1.043^{\mathrm{Bc}}$ & $1.148^{\mathrm{Bb}}$ & $1.252^{\mathrm{Aa}}$ \\
\hline
\end{tabular}

-Means followed by different capital letters in the same column are significantly different $(p \leq 0.05)$.

-Means followed by different small letters in the same row are significantly different $(p \leq 0.05)$.

Table 5. Prediction equations of alpha-amylase activity in different prepared doughs during storage at $-18 \pm 2^{\circ} \mathrm{C}$

\begin{tabular}{|c|c|c|}
\hline Dough samples & Prediction equations of $\boldsymbol{\alpha}$-amylase activity & $\mathbf{R}^{2}$ \\
\hline A & $\mathrm{y}=2.619(\mathrm{x})+77.79$ & 0.992 \\
B & $\mathrm{y}=2.808(\mathrm{x})+151.5$ & 0.980 \\
D & $\mathrm{y}=2.604(\mathrm{x})+97.49$ & 0.991 \\
AB & $\mathrm{y}=2.588(\mathrm{x})+178.1$ & 0.995 \\
AC & $\mathrm{y}=2.582(\mathrm{x})+129.6$ & 0.972 \\
BC & $\mathrm{y}=6.459(\mathrm{x})+185.7$ & 0.870 \\
DC & $\mathrm{y}=2.696(\mathrm{x})+130.8$ & 0.983 \\
ABC & $\mathrm{y}=2.345(\mathrm{x})+215.8$ & 0.993 \\
\hline
\end{tabular}

Table 6. Alpha amylase activity ( $\mu$ mole maltose $/ \mathrm{ml} / \mathrm{min}$ ) in pan breads made by frozen doughs after $1 \mathrm{~h}$ of baking and storage at $25 \pm 2^{\circ} \mathrm{C}$.

\begin{tabular}{|c|c|c|c|c|}
\hline \multirow{2}{*}{ Pan bread samples } & \multicolumn{4}{|c|}{ Alpha-amylase activity in pan breads made by frozen doughs stored at - } \\
\cline { 2 - 5 } & $\mathbf{0}$ & $\mathbf{1 4} \mathbf{1 4}$ days & $\mathbf{4 2}$ days & $\mathbf{7 0}$ days \\
\hline A & $0.561^{\mathrm{Ga}}$ & $0.475^{\mathrm{Gb}}$ & $0.386^{\mathrm{Ec}}$ & $0.273^{\mathrm{Gd}}$ \\
B & $0.752^{\mathrm{Ca}}$ & $0.639^{\mathrm{Cb}}$ & $0.506^{\mathrm{BCc}}$ & $0.460^{\mathrm{Cd}}$ \\
D & $0.583^{\mathrm{Fa}}$ & $0.490^{\mathrm{Fb}}$ & $0.398^{\mathrm{Dc}}$ & $0.325^{\mathrm{Fd}}$ \\
AB & $0.733^{\mathrm{Da}}$ & $0.633^{\mathrm{Cb}}$ & $0.534^{\mathrm{ABCc}}$ & $0.442^{\mathrm{Dd}}$ \\
AC & $0.661^{\mathrm{Ea}}$ & $0.590^{\mathrm{Eb}}$ & $0.440^{\mathrm{CDEc}}$ & $0.346^{\mathrm{Ed}}$ \\
BC & $0.786^{\mathrm{Ba}}$ & $0.657^{\mathrm{Bab}}$ & $0.549^{\mathrm{ABb}}$ & $0.515^{\mathrm{Bb}}$ \\
DC & $0.731^{\mathrm{Da}}$ & $0.611^{\mathrm{Db}}$ & $0.491^{\mathrm{BCDc}}$ & $0.097^{\mathrm{Hd}}$ \\
ABC & $0.857^{\mathrm{Aa}}$ & $0.674^{\mathrm{Ab}}$ & $0.618^{\mathrm{Ac}}$ & $0.555^{\mathrm{Ad}}$ \\
\hline
\end{tabular}

-Means followed by different capital letters in the same column are significantly different $(p \leq 0.05)$.

-Means followed by different small letters in the same row are significantly different $(p \leq 0.05)$. 
varieties, flour extraction rate and the bread type. Moreover, Poutanen, (1997) mentioned that the extent of $\alpha$-amylolysis during baking depends on the activity of the enzyme at the rather low water content and on its stability at the elevated temperature of baking. Results also indicated that, the initial activity of $\alpha$ - amylase was significantly $(p \leq 0.05)$ lower in $A$ followed by $D, A C$, both of $D C$ and $A B$, $B, B C$ and $A B C$, respectively. Additionally, the baking of pan bread caused a reduction in the activity of $\alpha$-amylase. Despite the reduction effect of baking temperature on the enzyme activity, an incremental pattern in $\alpha$-amylase activity was noticed for all fresh pan breads comparing with the $\alpha$ amylase activity in dough that were made from (Table 4). Such increase could be associated with the substantial increase of enzyme activity during the fermentation period prior to the bread baking.

Furthermore, by extending the frozen storage time of doughs up to 70 days at $-18 \pm 2^{\circ} \mathrm{C}$, a significant $(p \leq 0.05)$ reduction in $\alpha$-amylase activity was investigated for all pan bread samples after baking and storage at $25 \pm 2^{\circ} \mathrm{C}$. Where, the pan bread made by doughs stored for 70 days at $-18 \pm 2^{\circ} \mathrm{C}$ recorded lower $\alpha$-amylase activity comparing with pan breads made by doughs stored for 42 and 14 days, respectively. These results suggested that the ice recrystallization that occurs during the frozen storage of the dough cause some conformational changes which led to a significant decrease in a-amylase activity of baked bread.

Results in Table 7 reveal the residual activity of $\alpha$-amylase in pan breads made by frozen doughs after $72 \mathrm{~h}$ of storage at $25 \pm 2^{\circ} \mathrm{C}$. It could be noticed that, by increasing the storage time of pan bread up to $72 \mathrm{~h}$ at $25 \pm 2^{\circ} \mathrm{C}$, a clear reduction in $\alpha$ amylase activity for all tested pan breads was observed. Such decrease was strongly depending on the wheat variety and the type of yeast. Where, BC recorded the highest residual activity of $\alpha$-amylase followed by $A B C, A B, D, D C, B, A$ and $A C$, respectively. A similar trend was detected by Hemalatha et al (2014) who found that, the higher the residual activity of $\alpha$-amylase in bread, the increase in soluble starch and soluble amylose which in turn yielded soft textured bread.

On the other hand, there was a significant $(p \leq 0.05)$ decrease in the residual activity of $\alpha$ amylase in pan breads made by frozen doughs by increasing the frozen storage period of the dough at $-18 \pm 2^{\circ} \mathrm{C}$ up to 70 days. Where, $\mathrm{ABC}$ significantly $(p \leq 0.05)$ recorded the highest residual activity of $\alpha$ amylase $(2.77 \%)$ followed by $\mathrm{B}(1.92 \%), \mathrm{AB}(1.84$ $\%)$, BC (1.73\%), AC (0.93\%), DC (0.70\%), A $(0.36 \%)$ and $D(0.25 \%)$, respectively.

Table 7. Residual activity of $\alpha$-amylase in pan breads made by frozen doughs after $72 \mathrm{~h}$ of storage at $25 \pm 2^{\circ} \mathrm{C}$

\begin{tabular}{|c|c|c|c|c|}
\hline \multirow{2}{*}{ Pan bread samples } & \multicolumn{4}{|c|}{$\begin{array}{c}\text { Residual activity of } \alpha \text {-amylase (\%) in pan breads made by } \\
\text { frozen doughs stored at -18 } \mathbf{2}^{\circ} \mathbf{C} \text { for }\end{array}$} \\
\cline { 2 - 5 } & $\mathbf{0}$ & $\mathbf{1 4}$ days & $\mathbf{4 2}$ days & $\mathbf{7 0}$ days \\
\hline A & $37.77^{\mathrm{Ca}}$ & $23.06^{\mathrm{Eb}}$ & $6.35^{\mathrm{Cc}}$ & $0.36^{\mathrm{CDd}}$ \\
B & $39.68^{\mathrm{Ba}}$ & $30.25^{\mathrm{Cb}}$ & $10.67^{\mathrm{BCc}}$ & $1.92^{\mathrm{ABd}}$ \\
D & $40.25^{\mathrm{Ba}}$ & $27.06^{\mathrm{Db}}$ & $10.02^{\mathrm{Cc}}$ & $0.25^{\mathrm{Dd}}$ \\
AB & $44.81^{\mathrm{Aa}}$ & $30.45^{\mathrm{Cb}}$ & $11.56^{\mathrm{ABCc}}$ & $1.84^{\mathrm{ABd}}$ \\
AC & $37.25^{\mathrm{Ca}}$ & $30.89^{\mathrm{Cb}}$ & $12.23^{\mathrm{ABCc}}$ & $0.93^{\mathrm{BCDd}}$ \\
BC & $46.11^{\mathrm{Aa}}$ & $38.07^{\mathrm{Ba}}$ & $17.04^{\mathrm{ABb}}$ & $1.73^{\mathrm{ABCc}}$ \\
DC & $39.74^{\mathrm{Ba}}$ & $23.77^{\mathrm{Eb}}$ & $11.04^{\mathrm{ABCc}}$ & $0.70^{\mathrm{BCDd}}$ \\
ABC & $45.50^{\mathrm{Aa}}$ & $42.98^{\mathrm{Ab}}$ & $17.66^{\mathrm{Ac}}$ & $2.77^{\mathrm{Ad}}$ \\
\hline
\end{tabular}

-Means followed by different capital letters in the same column are significantly different $(p \leq 0.05)$. -Means followed by different small letters in the same row are significantly different $(p \leq 0.05)$. 


\section{Xylanase activity for tested wheat flours}

Xylanase activity in various tested wheat flours is presented in Table 8. Data demonstrated that, the activity of xylanase was significantly $(p \leq 0.05)$ higher in F1 than in other tested flours. Also, there were non-significant $(p \geq 0.05)$ differences in $x y$ lanase activity between F2 and F3 samples. Xylanase activity of F2, F3 and F4 was lower than the range estimated by Basinskiene et al (2011) while, F1 was in the range. These differences in xylanase activities among wheat flours may be due to the variation in wheat variety and the extraction rate of flour. Gys et al (2004) and Dornez et al (2006) mentioned that there are two sources of xylanase in wheat grains, endogenous endosperm xylanase and external microbial xylanases (constitute about $80 \%$ of total xylanase activity). It is worth to mention that, xylanase activity affects the water hydration properties of flour and provokes a redistribution of water in the dough (Simsek et al 2010). Jiang et al (2005), also, observed that $x y$ lanase activity influences the water absorption, development time, and stability, thus affects the dough strength. Xylanase activity also induces the redistribution of water, consequently modify the aggregation properties of gluten and changes the viscoelastic properties of dough (Steffolani et al 2010).

Table 8. Xylanase activity in different wheat flours

\begin{tabular}{|c|c|}
\hline Flour samples & $\begin{array}{c}\text { Xylanase activity ( } \mu \text { mole } \\
\text { xylose/ml/min) }\end{array}$ \\
\hline F1 & $0.123^{\mathrm{A}}$ \\
F2 & $0.083^{\mathrm{C}}$ \\
F3 & $0.083^{\mathrm{C}}$ \\
F4 & $0.095^{\mathrm{B}}$ \\
\hline
\end{tabular}

- Means followed by different capital letters in the column are significantly different $(p \leq 0.05)$

\section{Xylanase activity in different prepared doughs}

Xylanase activity was assessed in various freshly prepared doughs and was monitored throughout 70 days of frozen storage at $-18^{\circ} \mathrm{C}$ as shown in Table 9. It could be noticed that, xylanase activity was higher in all tested doughs comparing with that of the flour that were made from (Table 8). Meanwhile, xylanase activity was significantly affected by the type of flour and yeast. Xylanase activity in fresh tested doughs lies between 0.167 till $0.211 \mathrm{U} / \mathrm{min}$. Where, it was significantly $(p \leq 0.05)$ higher in $A C, D C, A B$ and $B C$ than that of the other prepared doughs. In contrary, $B$ and $A B C$ recorded the lowest xylanase activity. Using of compressed yeast in dough preparation caused a significant rise in xylanase activity compared to using active dry yeast, despite using the same type of flour except for the dough prepared from F4. Such differences in xylanase activity can be attributed to the variation of xylanase proportion that could bind to its endogenous inhibitors during enzyme extraction (Simsek et al 2010).

On the other hand, after 14 days of frozen storage, a significant $(p \leq 0.05)$ increase in xylanase activity was noticed in all tested doughs. Such increase ranged from $0.006 \mathrm{U} / \mathrm{ml}$ in $\mathrm{D}$ till $0.05 \mathrm{U} / \mathrm{ml}$ in $\mathrm{ABC}$ also it caused a decreasing in $\mathrm{pH}$ values (Fig. 1) which can be attributed to the production of simple sugars from the hydrolysis of non-starch polysaccharides. Subsequently, a significant $(p \leq 0.05)$ decrease in xylanase activity was observed by extending the frozen storage period of doughs up to 70 days at $-18 \pm 2^{\circ} \mathrm{C}$. This decrease in xylanase activity can be explained by the increase of $\mathrm{pH}$ values throughout the frozen storage of doughs. After 70 days of storage, the reduction in xylanase activity ranged from $0.03 \mathrm{U} / \mathrm{ml}$ in $B$ till $0.11 \mathrm{U} / \mathrm{ml}$ in $A C$ and $D C$ compared to its activity in fresh doughs. Furthermore, the doughs prepared with active dry yeast had higher xylanase activity than that prepared with compressed yeast. Also, B sample was significantly $(p \leq 0.05)$ higher in the activity of xylanase than other tested doughs while, $A C, A B C$ and $D C$ samples had the lowest xylanase activity.

Table 10 demonstrates the equations that predict xylanase activity in various prepared doughs within any period of frozen storage at $-18 \pm 2^{\circ} \mathrm{C}$. The linear regression analysis indicated that there was a significant correlation between the storage time of dough and xylanase activity $\left(R^{2}\right.$ were in the range of $0.816-0.981)$. It is important to mention that, the method used for obtaining these results use beechwood xylan as a substrate which differs in its structure from wheat arabinoxylans (McCleary and Mc-Geough, 2015), thus causing contradictions between the activity assay and the baking results so it can't be used solely to expect the functionalities of baking (Stinson, 2012).

\section{Xylanase activity in different pan breads made by frozen doughs}

Xylanase activity in different pan breads made by frozen doughs was assessed after $1 \mathrm{~h}$ of storage at $25 \pm 2^{\circ} \mathrm{C}$ as illustrated in Table 11. Data showed that, there were significant $(p \leq 0.05)$ variations in the activity of xylanase among bread 
Table 9. Xylanase activity in different prepared doughs during 70 days of storage at $-18 \pm 2^{\circ} \mathrm{C}$

\begin{tabular}{|c|c|c|c|c|c|c|}
\hline \multirow{2}{*}{ Dough samples } & \multicolumn{6}{|c|}{ Xylanase activity ( mmole xylose/ml/min) during frozen storage period (days) } \\
\cline { 2 - 6 } & $\mathbf{0}$ & $\mathbf{1 4}$ & $\mathbf{2 8}$ & $\mathbf{4 2}$ & $\mathbf{5 6}$ & $\mathbf{7 0}$ \\
\hline A & $0.186^{\mathrm{Bb}}$ & $0.213^{\mathrm{Da}}$ & $0.190^{\mathrm{Cb}}$ & $0.175^{\mathrm{Ac}}$ & $0.159^{\mathrm{Bd}}$ & $0.127^{\mathrm{Be}}$ \\
$\mathbf{B}$ & $0.167^{\mathrm{Cbc}}$ & $0.191^{\mathrm{Fa}}$ & $0.184^{\mathrm{Da}}$ & $0.173^{\mathrm{Ab}}$ & $0.163^{\mathrm{Bc}}$ & $0.142^{\mathrm{Ad}}$ \\
$\mathbf{D}$ & $0.192^{\mathrm{Bb}}$ & $0.198^{\mathrm{Ea}}$ & $0.196^{\mathrm{Ba}}$ & $0.154^{\mathrm{Bc}}$ & $0.133^{\mathrm{Dd}}$ & $0.112^{\mathrm{De}}$ \\
AB & $0.209^{\mathrm{Ab}}$ & $0.223^{\mathrm{Ca}}$ & $0.140^{\mathrm{Fc}}$ & $0.131^{\mathrm{Cd}}$ & $0.127^{\mathrm{Dd}}$ & $0.123^{\mathrm{Ce}}$ \\
AC & $0.211^{\mathrm{Ab}}$ & $0.247^{\mathrm{Aa}}$ & $0.208^{\mathrm{Ab}}$ & $0.169^{\mathrm{Ac}}$ & $0.165^{\mathrm{Ad}}$ & $0.100^{\mathrm{Ee}}$ \\
BC & $0.207^{\mathrm{Ab}}$ & $0.230^{\mathrm{Ba}}$ & $0.199^{\mathrm{Bc}}$ & $0.174^{\mathrm{Ad}}$ & $0.169^{\mathrm{Ae}}$ & $0.107^{\mathrm{Df}}$ \\
DC & $0.211^{\mathrm{Ab}}$ & $0.220^{\mathrm{Ca}}$ & $0.165^{\mathrm{Ec}}$ & $0.150^{\mathrm{Bd}}$ & $0.134^{\mathrm{De}}$ & $0.103^{\mathrm{Ef}}$ \\
ABC & $0.167^{\mathrm{Cc}}$ & $0.216^{\mathrm{Ca}}$ & $0.194^{\mathrm{Bb}}$ & $0.168^{\mathrm{Ac}}$ & $0.148^{\mathrm{Cd}}$ & $0.102^{\mathrm{Ee}}$ \\
\hline
\end{tabular}

-Means followed by different capital letters in the same column are significantly different $(p \leq 0.05)$. -Means followed by different small letters in the same row are significantly different $(p \leq 0.05)$.

Table 10. Prediction equations of xylanase activity for different prepared doughs during storage at $-18 \pm 2^{\circ} \mathrm{C}$

\begin{tabular}{|c|c|c|}
\hline Dough samples & Prediction equations of xylanase activity & $\mathbf{R}^{2}$ \\
\hline A & $y=-0.217(x)+35.05$ & 0.981 \\
B & $y=-0.129(x)+31.03$ & 0.957 \\
D & $y=-0.252(x)+34.38$ & 0.952 \\
AB & $y=-0.491(x)+38.45$ & 0.816 \\
AC & $y=-0.360(x)+41.81$ & 0.947 \\
BC & $y=-0.297(x)+38.88$ & 0.925 \\
DC & $y=-0.283(x)+35.08$ & 0.937 \\
ABC & $y=-0.292(x)+37.14$ & 0.975 \\
\hline
\end{tabular}

Table 11. Xylanase activity ( $\mu$ mole xylose $/ \mathrm{ml} / \mathrm{min}$ ) in pan breads made by frozen doughs after $1 \mathrm{~h}$ of baking and storage at $25 \pm 2^{\circ} \mathrm{C}$

\begin{tabular}{|c|c|c|c|c|}
\hline \multirow{2}{*}{$\begin{array}{c}\text { Pan bread } \\
\text { samples }\end{array}$} & \multicolumn{3}{|c|}{ Xylanase activity in pan breads made by frozen doughs stored at $\mathbf{1 8} \pm \mathbf{2}^{\circ} \mathbf{C}$ for } \\
\cline { 2 - 5 } & $\mathbf{0}$ & $\mathbf{1 4}$ days & $\mathbf{4 2}$ days & $\mathbf{7 0}$ days \\
\hline A & $0.267^{\mathrm{Ea}}$ & $0.232^{\mathrm{Fb}}$ & $0.198^{\mathrm{Ac}}$ & $0.118^{\mathrm{Bd}}$ \\
B & $0.261^{\mathrm{Fa}}$ & $0.220^{\mathrm{Hb}}$ & $0.194^{\mathrm{Bc}}$ & $0.128^{\mathrm{Ad}}$ \\
D & $0.268^{\mathrm{Ea}}$ & $0.228^{\mathrm{Gb}}$ & $0.149^{\mathrm{Fc}}$ & $0.104^{\mathrm{Dd}}$ \\
AB & $0.276^{\mathrm{Ca}}$ & $0.236^{\mathrm{Eb}}$ & $0.141^{\mathrm{Gc}}$ & $0.114^{\mathrm{Cd}}$ \\
AC & $0.290^{\mathrm{Aa}}$ & $0.247^{\mathrm{Ab}}$ & $0.181^{\mathrm{Cc}}$ & $0.078^{\mathrm{Fd}}$ \\
BC & $0.270^{\mathrm{Da}}$ & $0.245^{\mathrm{Bb}}$ & $0.170^{\mathrm{Dc}}$ & $0.097^{\mathrm{Ed}}$ \\
DC & $0.286^{\mathrm{Ba}}$ & $0.239^{\mathrm{Db}}$ & $0.181^{\mathrm{Cc}}$ & $0.069^{\mathrm{Gd}}$ \\
ABC & $0.266^{\mathrm{Ea}}$ & $0.242^{\mathrm{Cb}}$ & $0.165^{\mathrm{Ec}}$ & $0.064^{\mathrm{Hd}}$ \\
\hline
\end{tabular}

-Means followed by different capital letters in the same column are significantly different $(p \leq 0.05)$.

-Means followed by different small letters in the same row are significantly different $(p \leq 0.05)$. 
samples which were made with different formula. Also, xylanase activity was strongly affected by the variety of wheat, the type of yeast used in dough preparation and the period of dough frozen storage at $-18^{\circ} \mathrm{C}$. Concerning the activity of xylanase in pan bread made by freshly prepared doughs, it ranged between $0.290 \mathrm{U} / \mathrm{ml}$ in $\mathrm{AC}$ and $0.261 \mathrm{U} / \mathrm{ml}$ in $\mathrm{B}$. These values of xylanase activity were higher than those of the doughs which were made from (Table 9), although the reduction of enzyme activity during baking. This may be ascribed to the significant increase in xylanase activity during the fermentation of doughs. However, the activities of xylanase were lower than the values measured by Hemalatha et al (2010) as a result of the difference in the wheat varieties used and the type of bread produced. Moreover, pan bread made from F1 had higher xylanase activity than that of F2. Such findings were compatible with data reported in Tables $\mathbf{8}$ and 9. Besides, using of compressed yeast in dough preparation with $\mathrm{F} 1, \mathrm{~F} 2$ and $\mathrm{F} 3$ $(A C, B C$ and $D C)$ significantly $(p \leq 0.05)$ increased the activity of xylanase in baked bread compared to its activity when using active dry yeast $(A, B$ and $D)$. In contrary, $A B C$ was lower in xylanase activity than $A B$. Also, there was non-significant difference $(p \geq 0.05)$ in xylanase activity between $A, D$ and ABC.

On the other hand, by increasing the time of dough frozen storage at $-18^{\circ} \mathrm{C}$ up to 14 days, a significant $(p \leq 0.05)$ decrease in xylanase activity for all pan breads was observed. Despite that decrease, the activity of xylanase was higher in breads than in the dough they made from except for $A C$ which had the same value. Such reduction was almost varied between $0.02 \mathrm{U} / \mathrm{ml}$ in $A B C$ and $0.05 \mathrm{U} / \mathrm{ml}$ in $\mathrm{DC}$ compared to its initial value in fresh breads. Results also indicated that, by extending the time of storage for frozen doughs up to 70 days at $-18 \pm 2^{\circ} \mathrm{C}$, the activity of xylanase decreased significantly. Where, $B$ had the highest activity of xylanase followed by $A, A B, D, B C, A C$, $D C$ and $A B C$, respectively. The decrease in $x y$ lanase activity of baked bread may be due to the impact of the recrystallization of ice occurs during frozen storage of the dough on the structure of the enzyme.

The residual activity of xylanase in pan bread after $72 \mathrm{~h}$ of storage at $25^{\circ} \mathrm{C}$ is shown in Table 12. Data revealed that, there was a significant $(p \leq 0.05)$ reduction in the enzyme activity compared to its activity in bread after $1 \mathrm{~h}$ of baking (Table 11). A similar behavior was recorded by Hemalatha et al
(2014) who found a significant relation between the residual xylanase activity and the texture of bread. Such decrease in enzyme activity depended on the variety of wheat and the type of yeast. Concerning pan bread made by unfrozen dough, the reduction in xylanase activity ranged between $58.41 \%$ in BC and $75.46 \%$ in $\mathrm{B}$. Also, the pan bread made from $\mathrm{F} 1, \mathrm{~F} 2$ and $\mathrm{F} 3$ with compressed yeast (AC, BC and $\mathrm{DC})$ retained higher xylanase activity compared to those with active dry yeast (A, B and D). In contrary, the residual activity of $A B C$ was lower than that of $A B$. Interestingly, these results were consistent with the data in Tables 9 and 11. In addition, the longer the frozen storage time of dough at $-18^{\circ} \mathrm{C}$, the higher the decrease of xylanase residual activity in bread which varied among bread samples. The highest values of residual xylanase activity were found in $A$ and $B$ followed by $A B$ and $A B C$. While, $D C$ and $D$ had the lowest values $(0.53$ and $0.60 \%$, respectively) where the residual xylanase activity was about 74 and 47 times, respectively, lower compared to that in the bread made by unfrozen dough.

\section{$\mathrm{pH}$ values of different prepared doughs}

The values of $\mathrm{pH}$ were determined in fresh (after mixing) and frozen doughs (after thawing) as shown in Fig. 1. The initial $\mathrm{pH}$ values of different prepared dough samples were in the range of 5.25 (A) and 5.49 (ABC). The variation in $\mathrm{pH}$ among fresh dough samples was relatively small, approximately 0.24 units. After 14 days of frozen storage at $-18 \pm 2^{\circ} \mathrm{C}$, a slight decrease in $\mathrm{pH}$ values was noticed for all prepared doughs. This decrease was correlated with xylanase activity which produces fermentable sugars that have been consumed by the yeast, led to the increase in $\mathrm{CO}_{2}$ production and the decreased in $\mathrm{pH}$ (Haros et al 2002).

A gradual increase in $\mathrm{pH}$ values was observed for different dough samples by increasing the time of frozen storage at $-18 \pm 2^{\circ} \mathrm{C}$ up to 70 days. Such increase influenced the $\alpha$-amylase and xylanase activities (Tables 4 and 9). Moreover, the increase in $\mathrm{pH}$ values could be attributed to the accumulation of $\mathrm{NH}_{2}$ groups which are resulted from the dough weakening by the recrystallization of ice (Kim and Koh, 2002) and to the release of reducing substances from damaged yeast cells (Verheyen et al 2015). The change in $\mathrm{pH}$ values was little in D sample (0.003 unit/day) comparing with the other tested dough samples. It could be 
Table 12. Residual activity of xylanase in pan breads made by frozen doughs after $72 \mathrm{~h}$ of storage at $25 \pm 2^{\circ} \mathrm{C}$

\begin{tabular}{|c|c|c|c|c|}
\hline \multirow{2}{*}{ Pan bread samples } & \multicolumn{4}{|c|}{ Residual activity of xylanase in pan bread made by frozen } \\
& $\mathbf{0}$ & $\mathbf{1 4}$ days & $\mathbf{4 2}$ days & $\mathbf{7 0}$ days \\
\cline { 2 - 5 } & $27.64^{\mathrm{Ea}}$ & $19.57^{\mathrm{Db}}$ & $14.94^{\mathrm{Ac}}$ & $4.43^{\mathrm{Ad}}$ \\
A & $24.54^{\mathrm{Fa}}$ & $17.27^{\mathrm{Eb}}$ & $11.77^{\mathrm{Cc}}$ & $4.69^{\mathrm{Ad}}$ \\
B & $28.77^{\mathrm{Da}}$ & $5.98^{\mathrm{Hb}}$ & $0.57^{\mathrm{Ec}}$ & $0.60^{\mathrm{Ec}}$ \\
D & $40.73^{\mathrm{Ba}}$ & $28.34^{\mathrm{Bb}}$ & $7.49^{\mathrm{Dc}}$ & $3.61^{\mathrm{Bd}}$ \\
AB & $39.57^{\mathrm{Ca}}$ & $21.66^{\mathrm{Cb}}$ & $7.81^{\mathrm{Dc}}$ & $2.86^{\mathrm{CDd}}$ \\
AC & $41.59^{\mathrm{Aa}}$ & $30.80^{\mathrm{Ab}}$ & $12.57^{\mathrm{Bc}}$ & $2.61^{\mathrm{Dd}}$ \\
BC & $39.62^{\mathrm{Ca}}$ & $13.52^{\mathrm{Gb}}$ & $1.07^{\mathrm{Ec}}$ & $0.53^{\mathrm{Ec}}$ \\
DC & $27.75^{\mathrm{Ea}}$ & $14.60^{\mathrm{Fb}}$ & $7.21^{\mathrm{Dc}}$ & $3.48^{\mathrm{BCd}}$ \\
\hline
\end{tabular}

-Means followed by different capital letters in the same column are significantly different $(p \leq 0.05)$. -Means followed by different small letters in the same row are significantly different $(p \leq 0.05)$.
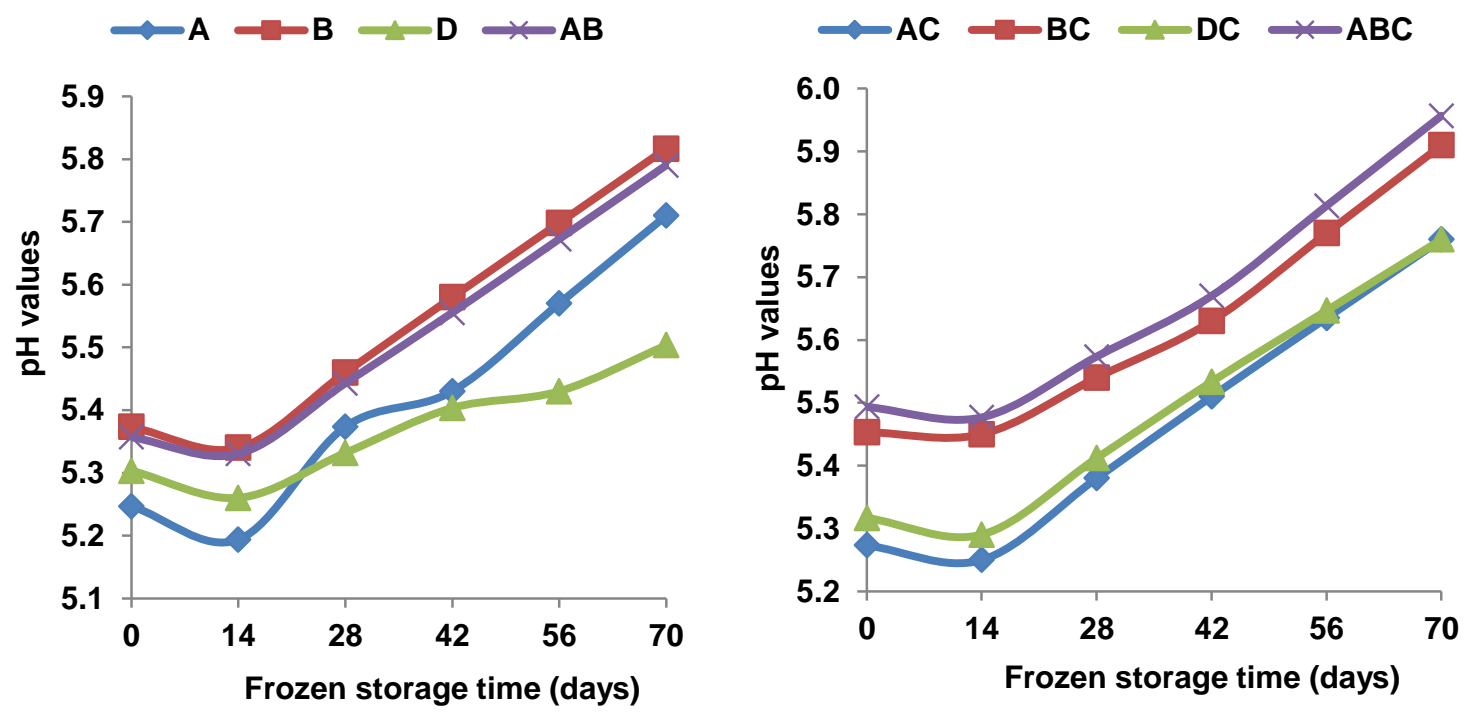

Fig. 1. Effect of frozen storage for 70 days at $-18 \pm 2^{\circ} \mathrm{C}$ on the $\mathrm{pH}$ values of different prepared doughs 
Table 13. Specific volumes of pan breads made by frozen doughs after $1 \mathrm{~h}$ of baking and storage at $25 \pm 2^{\circ} \mathrm{C}$

\begin{tabular}{|c|c|c|c|c|c|}
\hline \multirow[t]{2}{*}{ Pan bread samples } & \multicolumn{5}{|c|}{$\begin{array}{l}\text { Specific volumes }\left(\mathrm{cm}^{3} / \mathrm{g}\right) \text { of pan breads made by frozen doughs stored at - } \\
\qquad 18 \pm 2^{\circ} \mathrm{C} \text { for }\end{array}$} \\
\hline & 0 & 28 days & 42 days & 56 days & 70 days \\
\hline A & $3.56^{\mathrm{Da}}$ & $3.26^{\mathrm{Db}}$ & $3.07^{\mathrm{Dc}}$ & $2.93^{\mathrm{Dd}}$ & $2.90^{\mathrm{Cd}}$ \\
\hline B & $3.59^{\mathrm{BCDa}}$ & $3.41^{\mathrm{BCb}}$ & $3.19^{\mathrm{Cc}}$ & $3.17^{\mathrm{Cc}}$ & $3.04^{\mathrm{Bd}}$ \\
\hline D & $3.46^{\mathrm{Ea}}$ & $3.25^{\mathrm{Db}}$ & $3.05^{\mathrm{Dc}}$ & $2.93^{\mathrm{Dd}}$ & $2.89^{C d}$ \\
\hline$A B$ & $3.66^{\mathrm{BCa}}$ & $3.33^{\mathrm{CDb}}$ & $3.31^{\mathrm{Bb}}$ & $3.21^{\mathrm{Cc}}$ & $3.20^{\mathrm{AC}}$ \\
\hline$A C$ & $3.58^{\mathrm{CDa}}$ & $3.29 \mathrm{CDb}$ & $3.09^{\mathrm{Dc}}$ & $3.02^{\mathrm{Dc}}$ & $2.91^{\mathrm{Cd}}$ \\
\hline BC & $3.67^{\mathrm{Ba}}$ & $3.42^{\mathrm{BCb}}$ & $3.34^{\mathrm{Bbc}}$ & $3.30^{\mathrm{Bbc}}$ & $3.26^{\mathrm{Ac}}$ \\
\hline DC & $3.64^{\mathrm{BCDa}}$ & $3.52^{\mathrm{Bb}}$ & $3.37^{\mathrm{Bc}}$ & $3.13^{\mathrm{Cd}}$ & $3.02^{\mathrm{Be}}$ \\
\hline$A B C$ & $3.79^{\mathrm{Aa}}$ & $3.73^{\mathrm{Aa}}$ & $3.59^{A b}$ & $3.52^{\mathrm{Ab}}$ & $3.30^{\mathrm{Ac}}$ \\
\hline
\end{tabular}

-Means $(n=3)$ followed by different capital letters in the same column are significantly different $(p \leq 0.05)$.

-Means $(n=3)$ followed by different small letters in the same row are significantly different $(p \leq 0.05)$.

noticed that, when using the same type of flour, the $\mathrm{pH}$ values were higher for doughs prepared with compressed yeast than those prepared with active dry yeast.

\section{Specific volumes of pan breads made from fro- zen doughs}

Specific volume of bread is an important quality parameter which indicates dough expanding ability and oven-spring (Giannou and Tzia, 2007). Moreover, it is an indirect evaluation of crumb structure since too small loaf specific volume (LSV) indicates a very compact and closed structure, while too large LSV indicates a very open structure (Mohamed et al 2008).

The LSV of pan breads made from fresh doughs (without freezing) and frozen-thawed doughs stored at $-18 \pm 2^{\circ} \mathrm{C}$ up to 70 days are presented in Table 13. It could be observed that, the fresh $A B C$ exhibited significantly $(p \leq 0.05)$ higher LSV value $\left(3.79 \mathrm{~cm}^{3} / \mathrm{g}\right)$ than other fresh breads. While, the lowest LSV value $\left(3.46 \mathrm{~cm}^{3} / \mathrm{g}\right)$ was recorded in D sample. Also, a significant ( $p \leq 0.05)$ reduction in LSV was observed after 28 days of dough frozen storage for all bread samples. The reduction in LSV could be attributed to the ice recrystallization during frozen storage time (Berglund et al 1991). Subsequently by extending frozen storage time of different dough samples up to 70 days at $-18 \pm 2^{\circ} \mathrm{C}$, the LSV of bread baked from various tested doughs were significantly $(p \leq 0.05)$ decreased. The LSV of bread samples lies between $2.89 \mathrm{~cm}^{3} / \mathrm{g}$ for $\mathrm{D}$ and $3.30 \mathrm{~cm}^{3} / \mathrm{g}$ for ABC. A similar trend of LSV was found by Giannou and Tzia, (2007) who mentioned that bread sample is sensorially considered optimum when its specific volume is around $1.5 \mathrm{~cm}^{3} / \mathrm{g}$. The reduction percentage of LSV was comparatively lower in $B C, A B C$ and $A B$ than in the other breads. Such loss has been ascribed to the effect of freezing and frozen storage of doughs on gluten weakening and the reduction of both yeast viability and activity (Steffolani et al 2012).

\section{CONCLUSION}

The results of the present study concluded that, the physicochemical parameters and the enzymatic activities of flour are highly affected by the wheat varieties. Using of compressed yeast in dough preparation results in considerable decline of freezing point. $\alpha$-amylase and xylanase activities strongly affected by extending the frozen storage period of dough up to 70 days at $-18 \pm 2^{\circ} \mathrm{C}$. $\alpha-$ amylase activity was also used to predict the shelflife of frozen doughs. The longer the frozen storage time of dough at $-18^{\circ} \mathrm{C}$, the higher the decrease of bread residual enzyme activities. Enzyme activities in the doughs and pan breads strongly depended on the flour and yeast types. Pan breads prepared from doughs with a high alpha-amylase activity had better specific volumes. 


\section{REFERENCES}

AACC, 2012. American Association of Cereal Chemists. Approved Methods of Analysis. 11 $11^{\text {th }}$ Ed. St. Paul, Minnesota, USA.

Amjid M., Shehzad A., Hussain S., Shabbir M., Khan M. and Shoaib M. 2013. A comprehensive review on wheat flour dough rheology. Pak. J. Food Sci. 23, 105-123.

Bae W., Lee B., Hou G. and Lee S. 2014. Physicochemical characterization of whole-grain wheat flour in a frozen dough system for bake off technology. J. Cereal Sci. 60, 520-525.

Baratto C., Becker N., Gelinski J. and Silveira S. 2015. Influence of enzymes and ascorbic acid on dough rheology and wheat bread quality. Afr. J. Biotech. 14, 3124-3130.

Basinskiene L., Juodeikiene G., Kalvaityte V., Ceseviciene J. and Leistrumaite A. 2011. Enzyme activity of different cereals grown using organic and conventional agricultural practices. FOODBALT.

Berglund P., Shelton D. and Freeman T. 1991. Frozen bread dough ultra-structure as affected by duration of frozen storage and freeze-thaw cycles. J. Cereal Chem. 68, 105-107.

Bernfeld P. 1955. Amylases $\alpha$ and $\beta$. In: Methods in Enzymology, Volume 1. Sidney, P., Colowick, S. and Kalpan N. (eds.). Academic Press Inc., New York, USA, 1, 149-158.

Codina G. and Leahu A. 2009. The improvement of the quality of wheat flour with a lower content of alpha-amylase trough the addition of different enzymatic products. Ser. J. Agro. 52, 629635.

Courtin C. and Delcour J. 2002. Arabinoxylans and endoxylanases in wheat flour breadmaking. J. Cereal Sci. 35, 225-243.

Curic D., Karlovic D., Tusak D., Petrovic B. and Dugum J. 2001. Gluten as a standard of wheat flour quality. J. Food Tech. and Biotech. 39, 353-361.

Dornez E., Joye I., Gebruers K., Delcour J. and Courtin C. 2006. Wheat-kernel-associated endoxylanases consist of a majority of microbial and a minority of wheat endogenous endoxylanases. Agric. Food Chem 54, 4028-4034.

Every D. and Ross M. 1996. The role of dextrins in the stickiness of bread crumb made from preharvest sprouted wheat or flour containing exogenous alpha amylase. J. Cereal Sci. 23, 247256.

Ferrari M., Clerici M. and Chang Y. 2014. A comparative study among methods used for wheat flour analysis and for measurements of gluten properties using the Wheat Gluten Quality Analyser (WGQA). J. Food Sci. Tech. 34, 235242.

Gholamin R. and Khayatnezhad M. 2011. The effects of water and salt stresses on germination in two bread wheat genotypes. Afr. J. Biotech. 10, 17805-17811.

Giannou V. and Tzia C. 2007. Frozen dough bread: Quality and textural behavior during prolonged storage - Prediction of final product characteristics. J. Food Eng. 79, 929-934.

Goesaert H., Slade L., Levine H. and Delcour J. 2009. Amylases and bread firming - an integrated view. J. Cereal Sci. 50, 345-352.

Gomez M., Ruiz-Paris E. and Oliete B. 2011. Influence of wheat milling on low-hydration bread quality developed by sheeting rolls. Int. J. Food Sci. Tech. 17, 257-263.

Gys W., Courtin C. and Delcour J. 2004. Reduction of xylanase activity in flour by debranning retards syruping in refrigerated doughs. J. Cereal Sci. 39, 371-377.

Hamed A., Ragaee S., Marcone M. and AbdelAal E. 2015. Quality of bread and cookie baked from frozen dough and batter containing $\beta$ glucan-rich barley flour fraction. J. Food Quality. 38, 316-327.

Haros M., Rosell C. and Benedito C. 2002. Effect of different carbohydrases on fresh bread texture and bread staling. Eur J. Food Res. Tech. 215, 425-430.

Hemalatha M., Leelavathi K., Salimath P. and Prasada-Rao U. 2014. Control of chapati staling upon treatment of dough with amylases and $x y-$ lanase. J. Food Biosci. 5, 73-84.

Hemalatha M., Prasada-Rao U., Leelavathi K. and Salimath P. 2010. Influence of amylases and xylanase on chemical, sensory, amylograph properties and microstructure of chapati. J. Food Sci. Tech. 43, 1394-1402.

Hidalgo A., Brusco M., Plizzari L. and Brandolini A. 2013. Polyphenol oxidase, alphaamylase and beta-amylase activities of Triticum monococcum, Triticum turgidum and Triticum aestivum: A two-year study. J. Cereal Sci. 58, 51-58.

Jiang Z., Li X., Yang S., Li L. and Tan S., 2005. Improvement of the bread making quality of wheat flour by the hyperthermophilic xylanase B from Thermotoga maritima. Food Research Int. 38, 37-43.

Kim D. and Koh B. 2002. Freezing and fermentation curves of the dough frozen at different 
freezing condition. J. Food Sci. Biotech. 11, 99-104.

Kornbrust B., Forman T. and Matveeva I. 2012. Applications of enzymes in breadmaking. In: Bread Making: Improving quality. $2^{\text {nd }}$ Ed., Cauvain, S. (ed.). Woodhead Pub. Cambridge, UK. Ch.19. pp. 476-488.

Kozlowicz K. and Kluza F. 2001. Experimental characteristics of dough freezing and products obtained from frozen doughs. Elec. J. Polish Agric. Univ., 1-4.

Laaksonen T. and Roos Y. 2000. Thermal, dynamic-mechanical, and dielectric analysis of phase and state transitions of frozen wheat doughs. J. Cereal Sci. 32, 281-292.

Lebesi D. and Tzia C. 2012. Use of endoxylanase treated cereal brans for development of dietary fiber enriched cakes. Inn. Food Sci. Emer. Tech. 13, 207-214.

Mares D. and Marva K. 2008. Late-maturity $\alpha-$ amylase: low falling number in wheat in the absence of preharvest sprouting. J. Cereal Sci. 47, 6-17.

Matuda T., Pessôa Filho P. and Tadini C. 2011. Experimental data and modeling of the thermodynamic properties of bread dough at refrigeration and freezing temperatures. J. Cereal Sci. 53, 126-132.

Mc-Cleary B. and Mc-Geough P. 2015. A Comparison of Polysaccharide Substrates and Reducing Sugar Methods for the Measurement of endo-1,4- $\beta$-Xylanase. Appl. Biochem. Biotech. 177, 1152-1163.

Miguel A., Martins-Meyer T., Figueiredo É., Lobo B. and Dellamora-Ortiz G. 2013. Enzymes in bakery: Current and future trends. In: Food industry, Muzzalupo, I. (ed.). Intech. Ch. 14. PP. 287-301. http://dx.doi.org/10.5772/53168

Miller G. 1959. Use of dinitrosalicylic acid reagent for determination of reducing sugar. J. Anal. Chem. 31, 426-428.

Mohamed A., Rayas-duarte P. and Xu J. 2008. Hard red spring wheat/C-TRIM 20 bread: Formulation, processing and texture analysis. J. Food Chem. 107, 516-524.

Paucean A., Man S. and Socaci S. 2016. Wheat germ bread quality and dough rheology as influenced by added enzymes and ascorbic acid. Studia Ubb Chemia, Ixi. 2, 103-118.

Poutanen K. 1997. Enzymes: An important tool in the improvement of the quality of cereal foods. A Review. Trends in Food Sci. Tech. 8, 300306.
Rakita S., Torbica A., Dokic L., Tomic J., Pojic M., Hadnadev M. and Hadnadev T. 2015. Alpha-amylase activity in wheat flour and breadmaking properties in relation to different climatic conditions. Food and Feed Res. 42, 91-99.

Rani K., Rao U., Leelavathi K. and Rao P. 2001. Distribution of enzymes in wheat flour mill streams. J. Cereal Sci. 34, 233-242.

Rosell C., Aja S. and Sadowska J. 2002. Amylase activities in insect (Aelia and Eurygaster)damaged wheat. J. Sci. Food Agric. 82, 977982.

Salas-Mellado M. and Chang Y. 2003. Effect of formulation on the quality of frozen bread dough. Braz. Arch. Biol. Tech. 46, 461-468.

SAS 2004. "Statistical Analysis System". SAS User's Guide (Version 8.1). SAS institute Inc., CARY, NC, USA.

Selomulyo V. and Zhou W. 2007. Frozen bread dough: Effects of freezing storage and dough improvers. J. Cereal Sci. 45, 1-17.

Simsek S., Zhang Y. and Campanella O. 2010. Physicochemical properties of arabinoxylans in refrigerated dough. Int. J. Food Res. 43, 21192125.

Stathopoulos C., Tsiami A., Schofield J. and Dobraszczyk B. 2008. Effect of heat on rheology, surface hydrophobicity and molecular weight distribution of glutens extracted from flours with different bread-making quality. J. Cereal Sci. 47, 134-143.

Steffolani M., Ribotta P., Pérez G. and León A. 2010. Effect of glucose oxidase, transglutaminase, and pentosanase on wheat proteins: Relationship with dough properties and breadmaking quality. J. Cereal Sci. 51, 366-373.

Steffolani M., Ribotta P., Pérez G., Puppo M. and León A. 2012. Use of enzymes to minimize dough freezing damage. J. Food Bioprocess Tech. 5, 2242-2255.

Stinson J. 2012. A quantitative method to evaluate the effect of xylanases in baking. M. Sc. Thesis, Kansas State Univ., Manhattan, Kansas. $51 \mathrm{p}$.

Struyf N., Verspreet J. and Courtin C. 2016. The effect of amylolytic activity and substrate availability on sugar release in non-yeasted dough. J. Cereal Sci. 69, 111-118.

Verheyen C., Albrecht A., Herrmann J., Strobl M., Jekle M. and Becker T. 2015. The contribution of glutathione to the destabilizing effect of yeast on wheat dough. J. Food Chem. 173, 243-249. 


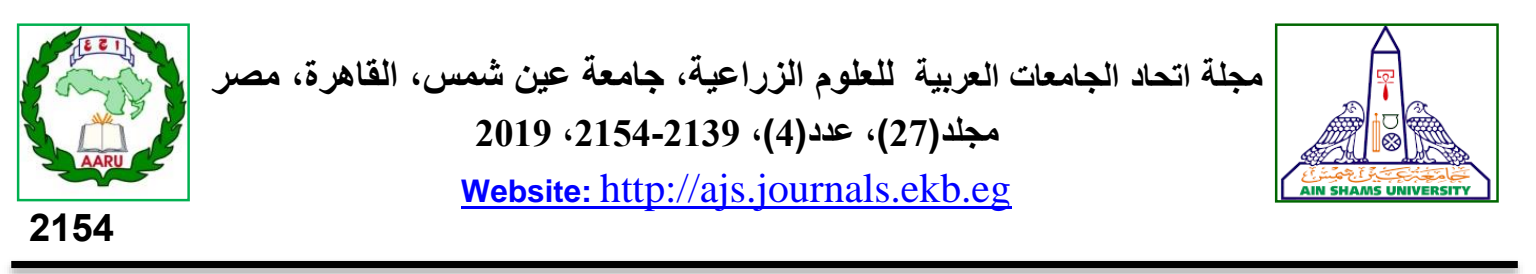

\section{تأثير نشاط إنزيمى الألفا أميليز و الزيايلانيز على خصائص العجائن المجمدة المحضرة من أصناف أقماح مختلفة}

[170]

$$
\begin{aligned}
& \text { إيمان كمال نبيه حنفى" - مجدى جمعه يس الثيمى - السيد إبراهيم يوسف - } \\
& \text { نسرين محمد نبيه يسن } \\
& \text { قسم علوم الأغذية - كلية الزراعة - جامعة عين شمس - ص.ب } 68 \text { - حدائق شبرا } 11241 \text { - القاهرة- مصر }
\end{aligned}
$$

*Corresponding author: dr_eman_kamal@agr.asu.edu.eg

Received 3 September, 2019 Accepted 29 September, 2019

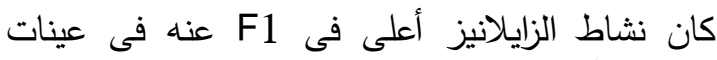

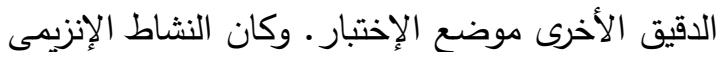

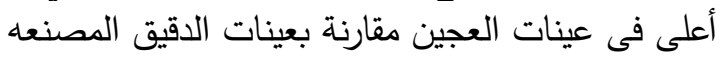

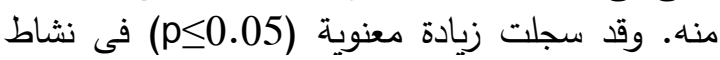
إنزيم الألفا أميليز بزيادة فترة تخزين التين العجين بالتجميد

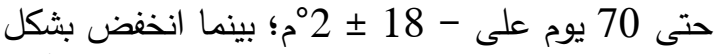

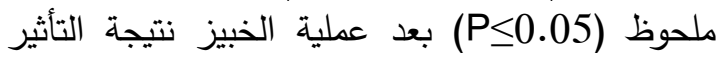

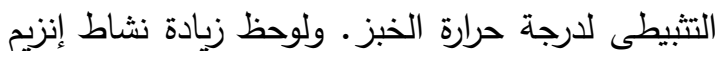

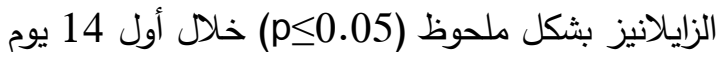

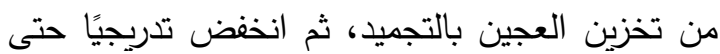

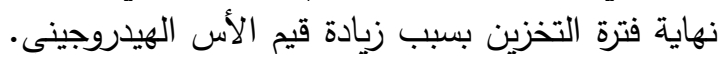

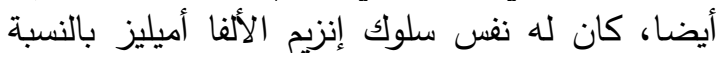

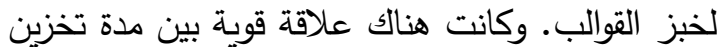

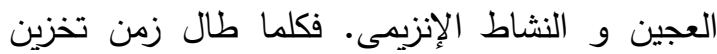

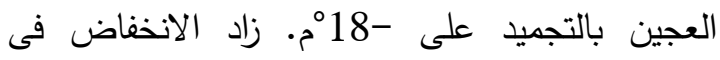

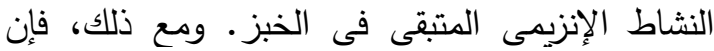

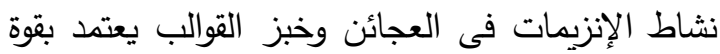

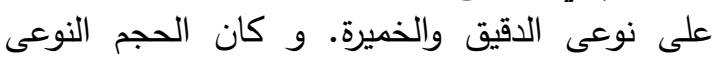

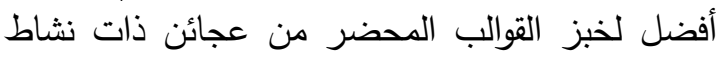

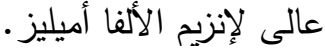

الكلمات الدالة: جودة دقيق القدح، منحنيات التجميد،

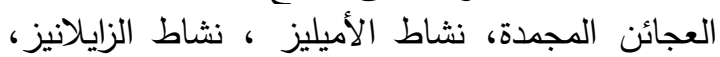

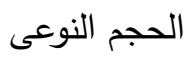

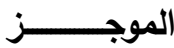

تهدف هذه الدراسة إلى تقييم نثاط إنزيمى الألفا

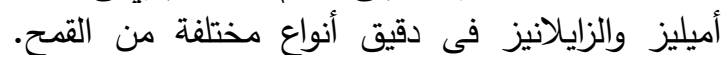
تمت دراسة الخصائص الفيزيائية والكيميائية المختلفة الفينة للاقيق. كما تم قياس الخواص الحرارية للعجائن

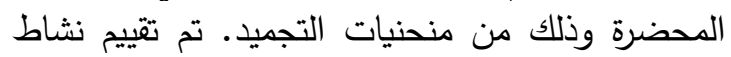

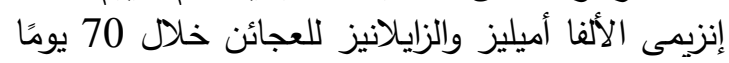

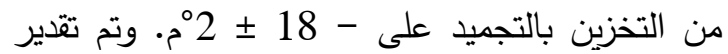
النشاط الإنزيمى المتبقى لخبز القوالب النئ المصنع من

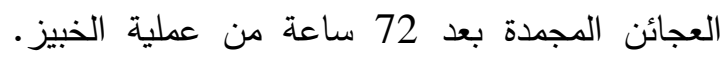
أظهرت النتائج أن الإختلافات في التركيب الكيميائي

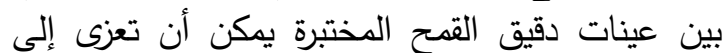
إختلاف أصناف القهح وكفاءة عملية الطحن. كانت

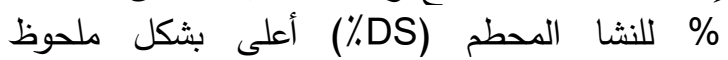

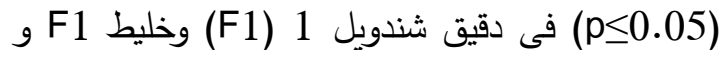

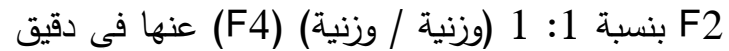

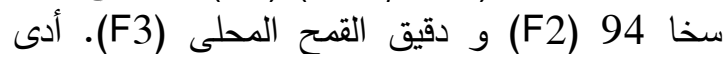
استخدام الخميرة المضغوطة في تحضير العجين إلى الى الى إنخفاض واضح فى نقطة التجمد ويمكن أن يعزى ذلك الكي

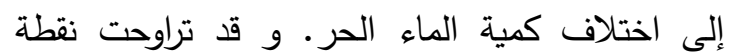

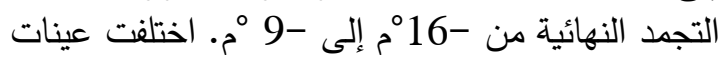

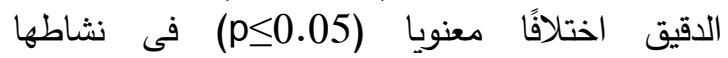
الإنزيمى، حيث كان لـ F4 أعلى نشاط لإنزيم الألفا

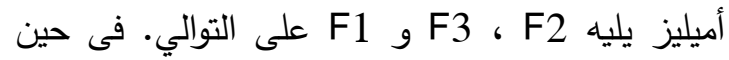

$$
\text { تحكيم: ا.د. يسرى أحمد عبدالدايم }
$$


